\title{
Understanding Women in the Religious Institutions: A Study With Reference To the Sattras of Assam.
}

\author{
${ }^{1}$ Padmakshi Kakoti, ${ }^{2}$ Pradip Jyoti Mahanta \\ ${ }^{1,2}$ Department of Cultural Studies, Tezpur University, India
}

\begin{abstract}
In India religious norms and values play a significant role in regulating the lives of women in many communities and most importantly the religious ones. As the role of women in modern day society has changed to a great extent so also the women in the Vaishnava religion as well as the religious institutions of Assam has remarkably changed and responded likewise. Women are mostly influenced by religiosity of the faith, highlighting the complex relationship between genders. The hegemonic structures and the hereditary control of the priestly class in these institutions also come under the frame of patriarchy. The paper has focused on the ways in which women were inspired by the ideals of the Vaishnavite movement started by Śankaradeva in Assam as also the institutional roles performed by them for maintaining a sustainable and positive environment. It is an attempt to contextualize the events that happened in history with the present state and provide an opportunity to appropriate their roles in the multi-faceted institutions like Sattra. However the paper discusses the general changing pattern of the roles of women in many of the influential Vaishnava institutions in Assam in particular, which have changed the traditional structure, both social and cultural.
\end{abstract}

Keywords- Congregations, Patriarchy, Religiosity, Sattra, Vaishnavism

\section{Introduction:}

Women and men have different experiences in the religious realm. It is an unprecedented phenomenon that women are more likely to be victimized in many phases of life, be it political, social or religious. Yet conditionally from the religious esteem women are prone to this victimization. As Ralph Pettman [1] observes, "In nearly every sphere of contemporary experience, women are made more vulnerable than men, and more susceptible to threat." To break them free of their traditional clutches, women are again neglected selves who very often tend to create a definite space of their own. Religiously women are better performers than men; they connect individuals in the community. This is in attunement to the role portrayed by the women folks in the socio-cultural and religious life of the Vaishnavite community in Assam in general and the Sattras in particular. Faith and belief in the system of worship has moderated the religiosity amongst the women belonging to this faith. But in earlier history of Vaishnavism in Assam women have been projected as lay and subordinated self in all aspects of life and society, although there are instances when women have moderated their self to a great height thereby contributing to the society. The women are excluded from the patriarchal hierarchy of the Sattras and are limited to a subordinated role within the institutions as well as the society. This propagates the traditional and submissive behaviour of the women which allows the male hierarchical order to remain in power and be authoritative. They have been assigned to have been playing the stereotypes in the male dominant society. The women's role exclusively in the 'religious' front as discussed in this paper has changed; it has brought uncertainties in their lives. Their participation in religion still represents a paradox.[2] Generally women of all ages are more likely than men to be described as religious, more affiliated to the respective religious organizations and report a more positive view on their participation. Women try to resituate themselves, express their religiosity, form their own agency and negotiate the social order within the context of their own faith. The religious practices which women undergo in the religious institutions provide them with a sense of solidarity and group spirit which enables them to face and address many of their everyday concerns in a collective way. Religious institutions are hierarchical[3], emphasizing the utility of super ordinate and subordinate relationships in the proper functioning of social systems, particularly in the family, where women are subordinated to the male head. Women apart from being practically into the household are generally supposed to be the transmitters of traditional values. They have however to a great extent fared well in the localized institutions; but at times they are kept secluded from these too which set rigid standards and operate on the basis of an established hierarchy. It has been a custom with the spiritual seekers at all times to have condemned women with a view to evoke detachment. The ideology of subordination is pervasive and has invaded the world view and ethos of almost the entire religious society, but there are exceptions which allow women a good amount of freedom and equality. The women act as the interlocutors in the society and play a multi-dimensional role in the affairs of that particular community to which they belong. In the trails of the history of the Vaishnavism in Assam too women have many a times confronted with discrimination as evident from the non-entry of women in the main prayer hall of one of the promising Sattras in Barpeta district of Assam set up by one of the chief disciples of the 
apostles of the faith. Patriarchy, thus on an intellectual level has become an integral part of religion and pervasive in the lives of the women folks. At times these issues become insurmountable but the women find out their own way of survival. They have created their own space and as such there are many Sattras in the whole of the state where women are the lone performers.

\section{1. $\square$ a $\square$ karadeva, Sattras and Women in the history of Vaishnavism in Assam:}

Srimanta Śa $\square$ karadeva, born in the middle of the fifteenth century Assam was the progenitor of the Vaishnava faith in Assam. With his magnanimous personality he tried to bring about a renaissance which later on gave the Assamese community their own identity and culture. The Vaishnava faith initiated by the saint is known as 'ek saran nama dharma' ie.devotion to one supreme God. The Sattras are a resourceful outcome of this faith. They are the repositories of socio-cultural and religious verve of the Assamese Vaishnava community. It was Śa $\square$ karadeva who showed special concern for the socially depressed and deprived where women took an important stand. Śa $\square$ karadeva and a few of his apostles however showed a special concern for the women and allowed a good amount of freedom and equality to them. Though the resources citing women in the Sattras are meagre yet there are a few instances in the history of the Sattras where women have been located and admired for their contributions. One of the distinguishing features of a Sattra is the creation of an ascetic kevaliya (a celibate devotee) order of monks, which has to a great extent superseded the women folks. As such there is no any order of nuns in these Sattras and the women are not allowed to mingle with the religious affairs nor do they mix with the men in congregations. According to the ek saran nama dharma the relation of man to God was like that of a servant to his sovereign, it was not like that of a woman to her beloved as postulated by other Vaishnava saints of the period. This may be the reason why the character of Radha, the female companion of Krisna in Hindu mythology as pronounced in the Radha-Krisna sect and the fiery power of unreflecting love are absent in Assamese Vaishnavism.[4]

Women too are considered for salvation. In practice however, women have not had any priestly role in the Sattras. Even now there are no such instances of a lady taking hold of a Sattra; all are administered and executed by men at the top-notch level. Yet to name one of such instance in the history of the Sattras where women took an active part in managing and administering the affairs of the Sattras. Śa $\square$ karadeva's own grand daughter in law, Kanakalata alias Laxmi Ai is a good example where she exemplified being the religious head for the first time in the history of Vaishnavism in Assam. With an extra ordinary zeal, she made definite contributions to the growth of the whole Sattra system and organized a group of twelve apostles and deputed them to various parts of Assam, deputing them to expand the Sattra network and to reach out to more and more people in different places. There are also a few Sattras originating from Śa $\square$ karadeva's daughters and great grand daughters, which have gained momentum in the later history of the faith and as regards to women's participation. The Sattras established by the descendants of Purusottama and Caturbhuja's daughters and sisters were known as nati sattras (establishments by grandsons), the ones established by the Thakura's grandsons are known as thakur-napata-sattra and the Sattras belonging to the line of Sankaradeva on the female side were known as srisankarar jiyari vamsar sattra [5]. Mention may also be made in this regard of Padmapriya, the first women poet and lyricist of the medieval era whose contributions have greatly enriched the genre of Assamese Vaishnava literature. Contrary to this liberal ethos prevailing in some Sattras, there is another scenario of medieval orthodox hierarchical attitude persisting against women in some other Sattras of lower Assam. Instances from the Sattra's attitude towards women of this bend has been vividly portrayed by one of the most influential Assamese novelist Mamoni Raisom Goswami[6] in her acclaimed novel, The Moth Eaten Howdah of the Tusker. The story set in one of the Sattras of Assam is about the plight of a widow whose spirit is humiliated by the patriarchal world views who embraces death because of the feudal economic order underpinning the religious conservatism prevalent in the society then. Renunciation of the world, yet another mystical theme that underpins all religions of the world has not been eulogized by the saint. Rather the biographies of him reveal the fact that he was the one who favoured the life of a householder. Moreover if we look at the history of Vaishnavism in Assam and Śa $\square$ karadeva's contributions towards the upliftment of women it can be assumed that he was in full consideration for the spiritual well being of the women.

\subsection{Participatory role of women in the Sattras:}

A peep into the history of the Vaishnava faith would reveal the fact that women's role was a passive one. Inspite of all these trajectories concerning the eventual changes in the lives of women getting into the threshold of a religious set up, yet there are noteworthy exceptions too. The biographies of Śa $\square$ karadeva mention his declination to ordain women into his faith on the ground that they would not be able performers. In later years this was made conducive by the fact that the women became the devout 'bhakta'. Except for the sacramental practices carried out by the male counterparts, women have been able to make a place of their own. The relation of women to the institution with the Sattras is not new and in several ways it reflects the dynamics of a social structure and the process of social transformations within a specific social context. Women's participation plays a significant role in most of the Sattras of Assam, mostly the liberal and heterodox branches 
of the sect where they are not distanced from men, despite the fact that no female deity is worshipped in Śa $\square$ karadeva's system of religion. In such branches of the sect, women are generally not debarred from participation in any socio religious activities. In the cultural arena too women are debarred from participating. The Sattras have excelled in various art forms, contributing immensely to the growth and development of the Assamese culture since the days of its inception and it has been able to maintain it still. So far the history goes Śa $\square$ karadeva did not assign any role to the women to perform in public, be it in the form of dance, drama or music. There are infact no evidences in support of it where they have protested or have made a public appearance, though the reservation made in the faith say free mixing and equal participation irrespective of the gender discrimination. But this notion has changed. The change is more transparent in other sub sects within Assamese Vaishnavism where the practice of ordaining and initiation women is more prevalent. Their equal footing and creation of an alternative space have enabled them to express their leadership qualities and a way to express themselves. Women's representation within the governing structures of the Sattras, remains negligible, a fact made all the more obvious because they tend to constitute the largest section of the congregation and provide the most labour, particularly for the special sittings of prayer during several important occasions. A woman from the lower strata conjoins the women of high caste in the congregations and this feature is notable during the community näm-prasangas held in the nāmghar (prayer-halls) regularly and also on special occasions like the birth and death anniversaries of the great apostles of the faith, sacred festivals etc. Through the present study it has been observed that in most cases, the liturgical practices and rituals are done by the male dignitaries in the Sattra. But the women also hold their own positions and are allowed to be a part of all the religious proceedings and it has been taken into note that their participation is larger than the males in comparison. The women as daily performers in the Sattras have emphasized more on the individual spiritual development of the self. While at the same time, these women have played a significant role in preserving the traditional doctrines and day to day practices. This resulted in an environment where gender categories are not fixed. The study has suggested that the spiritual gains might have restricted the tendency towards conservatism which is noticeable in other prominent Sattras of Assam. With the egalitarian revivalist spirit of the Vaishnava faith, new measures are in vogue encouraging women to participate and speak in mixed prayer meetings and congregations. The women in the villages generally form collective groups known as got keep accounts for the larger benefit of the women folk in the village. Often the Sattradhikara (head of the Sattra) of the particular Sattras under which they are affiliated becomes the beneficiary and help them to earn profits. A group leader is being appointed who takes care of the religious proceedings in the Sattras as well as the societal developments. The profit is later utilized by the got in organizing various activities within the village premise. Women thus have been instrumental in laying considerable influence in drawing people from the neighborhood as well as from their own community into the fold. Even traditional religious groups such as the nāmoti $d o l$ often discusses social issues in the namghar and work closely with members of the mahila samitis (groups formed by women in the village for various socio- economic developments)which have been established in their respective towns and villages. This way they are contributing to the economic growth of the institution in general and the Assamese Vaishnava community in particular.

\subsection{An overview in present times:}

If a panoramic view is cast on Vaishnavism in Assam today, it is seen that women occupy a very important place as they do in all social spheres. This is applicable to their conditions as both practitioners and believers. As mentioned at the beginning, the subordination of women has been in our society since long. Liberalism which marked the initial stage of the history of Vaishnavism in Assam was later on replaced by conservatism so far as its attitude towards the women folk is concerned. [7] These institutions set rigid standards and operate on the basis of an established hierarchy though this was not implicit in the preaching and holistic attitude of the saint himself which stood for humanism based on the notions of egalitarianism and social justice. From the information and observations collected from the fields, it is known that the Sattras have a variety of attitudes with regards to the women folk. They are allowed a good amount of freedom and equality. The participation of women in the Namghar (prayer hall) is noteworthy where the women generally organize the congregational prayers known as duprasanga (prayers held by women only at afternoon) at regular intervals. This is another notable feature which has defined the non-obligatory performances exclusively by women in the religious domain. Their roles in the socio-religious affair of these institutions are distinctly set by their active participation rather than being influenced by sexual discrimination. On many occasions on the other hand the management committees of the Sattras are still male dominated and have traditional male stereotypes. However instead of being repressive but they have provided a space for the women folks as they tend to constitute the larger section of the congregation and provide the most of the physical labour. Presently the role of the women is at par with the men in many of the Sattras where they are given an equal footage. The ideology of subordination is not pervasive here as the study shows how importantly the women are treated irrespective of all caste and creed. Status tends to be used perfectly as a self evident concept as the participation of women in the namghar (a prayer hall in the precincts of the Sattra or outside) as well as on the important occasions has been 
explicitly denoted where women are entitled to free passage and entry in the Sattra threshold and they are entitled to many smaller roles to partake when need arises. The participatory role of the women both from the gentry and the lesser privileged are different in respect to the division of sects made by the saint himself. In some of the Sattras women are debarred from entering the premises of the main prayer hall. Yet relatively they are more spiritual, religious minded and dedicated selves who have delivered their duties in an organized manner since the days of the inception. In many of these Sattras there is a provision for a separate nāmprasangas (devotional services consisting of prayers, recitation of hymns and religious discussions.) exclusively for women which are done only by the females irrespective of all caste and creed. These are held either in the Sattra premise or in the village namghar and at times the women keep chanting the dihā-nams (a form of congregational chanting within the session) illustrating the recitals from the Kirtana(devotional epic by Srimanta Śa $\square$ karadeva). The socio-economic status of women has greatly being influenced by these socio-religious institutions.

\section{Conclusion}

If women ever participated in the socio- religious affairs of these institutions as passive onlookers, much of the form and content of that participation must have been influenced by gender discrimination. With passage of time great variations in thought and practice, as well as in the status and role of women in these institutions is noticed. The Sattras in general as discussed in this paper had brought to light many such deliberations which have been at par with the men folks. Static models of women as the muted and the marginalized have been relegated by the ways in which they project their roles in these Sattras and their role prominently in the community affairs right from the regular congregations to other related religious undertakings. Though in several cases, women have fared well in the localized institutions like the Sattras yet their lives are constrained by the overall conservative outlook and are often kept secluded from the institutional norms and conditions. One of the main reasons behind this equal footage is the growth of many Purusa Samhati (the sub sect organized by Purushottam Thakur,an important apostle of the faith) Sattras mostly scattered in most of the influential areas which claim to have retained the original features of Śa $\square$ karadeva's faith. Within the imperatives of reciprocity, even if both men and women enjoy complete autonomy, deeper problems concerning attitudes towards women however on several other aspects still remain. No doubt there may be restrictions on women's public sphere participation in most of these institutions following the Vaishnava faith, but its effect may be treated as universal as conceived in yesteryears. Thus this is neither subjugation nor subordination in real sense; it is self determination and self assertion which would not hamper the liberty of women and aspire to her full humanity in the long run. Modern Vaishnava society in Assam has to a great extent stopped to relegate both religion and women to an isolated sphere, not to keep them out of touch with the broader forces of economic and political life. As women are emerging from that enforced isolation, a significant number of them may certainly bring religion into the public sphere along with them. This was however not previously envisioned. The need of the hour is women must come out of their stereotypical domain and engage themselves in every possible way in order to grow their spiritual self.

\section{References:}

[1]. Ralph Pettman, "Human Security as Global Security: Reconceptualising Strategic Studies," CambridgeReview of International Affairs 18, no. 1 (April 2005), 137-150.

[2]. Elizabeth W. Ozorak, The power but not the glory: How women empower themselves through religion Journal for the Scientific study of Religion, 35(1), 1996, 17-29.

[3]. J. DiSalvo, Class, gender, and religion: A theoretical overview and some political implications, in J. Kalven and M. I. Buckley (Eds.), Women's Spirit Bonding (The Pilgrim Press: New York, 1984)

[4]. Jyoti P. Rajkhowa, Sankardeva: his life preachings \& practices, a historical biography (B.S. Publications: Guwahati, 2012).

[5]. Maheswar Neog, Early History of the Vaisnava Faith and Movement in Assam (New Delhi: Motilal Banarasidass, 1965).

[6]. Mamoni Raisom. Goswami, The moth eaten howdah of the tusker (Rupa: New Delhi, 2005)

[7]. S.N. Sarma, The Neo-Vaisnavite Movement and the Satra Institution of Assam (Lawyer's Book Stall, Guwahati: Sreekanta Press, 1996) 